\title{
Reporting Religion and Enemy Images in the Nigerian Press
}

\author{
ODAMAH ALIYU MUSA, Liverpool Hope University
}

\begin{abstract}
The Nigerian press is sharply polarised along geographical, ethnic and religious divides. In reporting religion the overbearing effect of the North-South divide easily impacts on the audience, creating a negative perception of the other - Christian-majority south versus the Muslim north. From the early 1980s up until this year, Nigeria repeatedly saw the eruption of religious conflicts between Muslims and Christians. The media are blamed for either instigating or amplifying the crisis or both. Using interviews and content review of reports, this paper seeks to examine issues like the use of newspapers in providing platform for promoting religious disharmony, manipulation of journalists reporting religion and how it impacts on fairness and objectivity and the process of creating stereotypes. Applying Sherif's Superordinate Goals model, we explored the possibility of confronting the common problems for the collective interest of the entire nation. The paper proposes researching into and reporting on the positive sides of other faiths as a means of eradicating negative images and promoting religious tolerance and peaceful coexistence in Nigeria and beyond.
\end{abstract}

\section{KEYWORDS}

Reporting religion, stereotypes, Nigerian media, religion, conflict

The history of the print media in Nigeria dates back to the late $19^{\text {th }}$ century when the first newspaper was established. Salawu (2006) observes that Iwe Irohin Fun Awon Ara Egba ati Yoruba was founded in 1859. The newspaper, according Salawu, was based in where was to become South-Western Nigeria and that it was published in native Yoruba language. Iwe Irohin was also the first indigenous language newspaper in Africa.

Other newspapers later emerged and were published in indigenous languages that included Eko Akete (Yoruba) in 1922 and Gaskiya Tafi Kwabo, which was founded in 1937 and was published in Hausa. Also in 1937, the West African Pilot, an English language newspaper was founded and based in Lagos (Salawu, 2006).

One important factor that strongly encouraged the emergence of newspapers in Nigeria was the presence of Christian missionaries and the chief aim, then, was to ease communication through reading and writing. Whereas missionary activities were freely extended across Southern Nigeria, Hackett (2003, p.53) notes that in line with the British (colonial) policy of non-intervention in the Muslim North, they were restricted. This, according to Hackett, was a serious setback to Western education including the early development of mass media in the region. It was to create a striking imbalance as the North pathetically lagged behind its Southern counterpart, whose over a century-old journalistic tradition ensured its domination of the media and their concentration in Lagos and Ibadan, in the South of the country. Apart 
from their concentration in the South, media ownership was, until very recently, a complete monopoly of non-Northern proprietors. In reference to this problem and other underlying issues, Igbo (1997, cited in Hackett, 2003, p.53) posits that the much talked imbalance in the country stems from the advantages gained by those who received Western education.

From the late 1980s a number of key events that redefined relations between Muslims and Christians in Nigeria took place. Nigeria's dwindling economy and increased commercialisation of the media, particularly the print, were among those. With looming poverty and increasing uncertainty the atmosphere became quite charged and simple disagreements often led to violent reactions. Incidentally, commercialisation saw the number of privately owned newspapers soar. Some of these, as Hackett argues, were faith-based or had as their focus the defence of certain religious faiths.

In the ensuing sectarian conflicts many news organisations within the country were accused of pitching tents; in relations to the region they are based or the religious faith they're assumed to be sympathetic to. Hackett (2003) opines that they then, as they still do now, constituted one of the principal locations for the propagation and representation of religious groups.

A test case for this assertion was the religious violence of Kafanchan (Kaduna State) in 1987; the media were accused of actively fuelling it. In 1991, Nigerians again watched in horror as Muslims and Christians clashed in Tafawa Balewa and Bauchi (in Bauchi State). Again, Kaduna State saw a repeat of the ugly events of Kafanchan in Zangon Kataf, where sophisticated weapons were allegedly used and thousands of people were killed or injured, several hundreds of others became internally displaced.

Jos, the capital of Plateau State, is a tin-rich city in the middle of Nigeria. Priding itself as the 'home of peace and tourism' (Plateau State, n.d.), it has the most clement climate in the country and visiting westerners often found it nearly as comfortable as their countries of origin. Around the time the crises in Bauchi and Zangon Kataf erupted Jos automatically became a focus and everyone was just waiting for the worse to happen. In 1994 a mild altercation took place following the appointment of a Muslim (settler) to a Federal position to fill the state's slot. Although what could have been a major crisis was averted by the quick intervention of the government, the real problem was only postponed.

On 7 September 2001 Plateau was up in flames again. Unlike the previous crisis this one was reportedly pre-planned and carefully executed. It continued as a series of conflicts lasting nearly four years, costing thousands of lives (including women, children and the aged) and property worth several millions of dollars. In the same vein more than a quarter of a million people were internally displaced as villages and towns were totally devastated.

There have been questions asked whether all these conflicts are religious or they are caused by factors outside of religion. The crises in Plateau, as well as other religious conflicts in Nigeria, are hardly religious, commentators, scholars and observers would argue. For instance Hackett (2003) observes that in Nigeria the main causes of these conflicts were often economic, political and or ethnic issues manipulated and labelled religious. The role of the media in amplifying the problems, however, remains controversial. Kukah (1990) argues that the media have always contributed in fanning and sustaining the embers of bigotry in the country. In the Kafanchan violence, Ibrahim (1989) accused the media, specifically the New Nigerian Newspaper and the Federal Radio Corporation of Nigeria, both government-owned 
and based in Kaduna, Northern Nigeria, of inciting people to murder by emphasising the reign of 'terror' and the killing of Muslims in Kafanchan. But Kukah (1996) incidentally rose in defence of the media, arguing that reports on the crisis were not sensationalised and that all provocative stories had been expunged from news items published or broadcast by the New Nigerian Newspaper and Federal Radio Corporation of Nigeria respectively. More than any other situation sectarian conflicts in Plateau State have repeatedly contributed in creating a wide gulf between newspapers in Northern Nigeria and those in the South. For the purpose of this paper I will use the Jos religious violence of November $28^{\text {th }} / 29^{\text {th }}$ to buttress this argument.

Even though Plateau State is often described as part of Northern Nigeria majority of the indigenes, who are Christians, resent this description and prefer calling themselves 'MiddleBelters'. With nearly 70 of its population non-Muslim and speaking languages other than Hausa - the dominant language in the North - they see themselves as different and would want to maintain that distinct identity.

However, in Jos, the state capital, it is arguable that the majority of the population are Muslims or non-natives. But the indigenous people claim these people are settlers from other states that have lived on their land and dominate the economy (Jos, 2007, n.p.). In the last 30 years this has been a very hot issue and from September 2001 has provoked violent clashes between the indigenes and settlers. At the climax of the crisis a whole town, Yelwa Shendam, was sacked and hundreds of thousands of people - including children and women - were either killed or captured and taken into slavery. As a result of the failure of the state government to control the violence the state governor, Chief Joshua Dariye, was suspended from office by the then president, Chief Olusegun Obasanjo. It took the deployment of federal troops to maintain peace, even as highly sophisticated weapons were said to have been used freely.

Although peace returned to the state the situation continued to remain one of mutual suspicion and anxiety. Meanwhile, so much like the situation in Northern Ireland, residential segregation became the new feature of relations between Muslims and Christians or Settlers and Indigenes in the state. For instance people who were lucky enough that their homes were not destroyed during the violence found that they could not return to those. Almost in all cases people had to either abandon such property or swap with other people who are of different religious affiliation and facing similar problems in their community.

After four years of what was at one point described as 'peace of the grave yard' Jos was up in flames again from 28-29 November, 2009. On November 27, Local Government elections were held in the state and the Jos electorate were divided on the basis of religion. The two main rivals were Aminu Baba and Timothy Buba, a Muslim and a Christian candidate, respectively; they also represented the two main groups ie settlers and indigenes.

In the election for Jos North Local Government Chairman it was alleged that the state government had a preference for the Christian candidate, who is also the governor's kinsman and family friend. It was further claimed that the governor had planned, in collaboration with the state electoral commission officials, to rig the election in favour of their preferred candidate. It was later rumoured that the whole process had been manipulated and supporters of the Muslim candidate went into the streets protesting even before the results were released. It was at this point that the anti-riot police and military men were sent to the scene leading to the shooting and killing of many of the protesters. The state governor, David Jonah Jang, 
reportedly gave a 'shoot-on-sight' order to security officials and by the next day reports claimed up to 500 people, mainly from the rival group had been shot dead. In the midst of it all, results of the elections across the state were released, including the one disputed in Jos.

Most of the reports made on the crisis were from international media like the BBC, CNN, VOA, Islam Channel and the Al Jazeera English. The reports were mostly balanced and Islam Channel was particularly quite investigative as its correspondent visited victims at various refugee camps and interviewed them.

However, the same cannot be clearly said about the local press. There were allegations that within Nigeria news reports were not very balanced and, to a large extent, only reflected certain interests. For instance Daily Trust and its Weekly and Sunday versions were said to have mainly focused their reports on Muslim and Northern victims. In the case of other newspapers like the Guardian, This Day, Punch, Tribune etc, which are based in the South, their reports only featured Southern victims living in the North. For instance, among the victims were three fresh university graduates doing their mandatory National Youth Service in Jos. They were allegedly murdered by hoodlums from the Muslim side. There were also school pupils whose classrooms were invaded by hoodlums from the Christian side, it was claimed. Many of them, in their early teens, lost theirs lives or were left with serious injuries. But there were allegations that while the graduate victims received full blown media coverage from Southern press they (Southern or Lagos-Ibadan axis media) imposed a blanket blackout for the other victims.

Mohammed Haruna, a columnist with Daily Trust, argued the other victims were ignored because they were Muslims and Hausa-Fulani and the newspapers are owned by Southern/Christian proprietors.

Mr Haruna, who accused the Plateau State government of grave complicity in the crisis, was to provoke outrage and reactions from both readers and writers from the Christian side. He claimed receiving about 550 text messages fully loaded with what he described as venom. 'From the pure venom, however, the text that took the cake was the one that said I was a 'BASTARD CONCEIVED from a busted CONDOM' for criticising Governor David Jonah Jang,' he said.

Although he said he was despondent in the face of such criticism, he blamed the politicians, the media and the clergy - both Muslim and Christian - for not effectively playing their roles to prevent the conflict. Commenting on the media and the clergy he explained: 'The one is supposed to be the society's watchdog and the other its conscience.'

Mr Haruna particularly expressed disappointment over Archbishop John Onaiyekan's onesided condemnation of the killings. The Catholic archbishop of Abuja and President of the Christian Association of Nigeria had been reported criticising the violence in Jos, specifically the killing of the Youth Corp members, as evil. But he did not condemn the attack on Muslim victims, not even the pupils' killing. Mohammed Hurana, despite saying Archbishop Onaiyekan is a highly respected and highly principled man of God, did not hide his disappointment at his failure 'to express the same anger over the cold-blooded murder and maiming of innocent children at an Islamic school during the same riot.' He went on to say that: 'It is, I believe, the lack of even-handedness in reporting and condemning political violence that camouflages as religious violence by both the media and the clergy which is the greatest obstacle against the emergence of democracy in Nigeria.' 
The columnist also suggested that both the media and the clergy should have preached that the dichotomy between 'indigenes' and 'settlers' was false and that everyone had settled in the place at some point. And that such division would only serve to deter a society's progress. Further on the issue of media fuelling such tension, he referred to the crisis in May 2004, when hundreds of innocent citizens were killed in Yelwan Shendam; the defunct Comet (June $21,2004)$ had written that the 'settler class' had in spite of the creation of states 'continued to load and lord it over the aborigine.' In contrast to this statement he pointed out what he called a more sensible position by Punch (June 23, 2004) that 'all Nigerians should be able to feel at home in any part of the country with their political and other rights fully guaranteed.'

Challenged to proffer solution to the problem, Mohammed Haruna, while not missing a chance to hit at Mr Jang, accused the governor of openly showing to the Hausa settlers that they were only second class citizens in the state and that he defined the Middle-Belt as a Christian-only enclave. Yet the writer returned to his earlier suggestion that it was the media and the clergy's responsibility, irrespective of who owned or controlled them, to debunk beliefs such as Jang's.

More than sending a text message Jonathan Ishaku, himself a journalist and former editor of Standard newspapers owned by Plateau State government, rose firmly in defence of Governor David Jonah Jang. He accused Mohammed Haruna of being a bigot and supporter of the Hausa-Fulani/Muslim extremism. Particularly, he accused him of being least qualified to accuse the press of fuelling the embers of hatred or amplifying conflict. He based his position on a particular situation during one of the previous sectarian conflicts, when Haruna used his position as the Managing Director of the government-owned Daily Times newspaper to further the interest of Muslims to the disadvantage of Christians, and, in fact, to fuel the conflict by publishing an advertorial. This advertorial had been declined by the editor of the same newspaper, but Mr Ishaku claimed Mr Haruna bypassed the editor to get it published, risking whatever consequences would follow.

Whereas it was a period of national bereavement following the catastrophe in November 2008, both Mohammed Haruna and Jonathan Ishaku spent more time taking on each other. In the same manner the press were used as a platform for advancing such positions. However, there were moments when, in spite of the urge to rally behind a party some journalists chose to call for a general rethink.

Adamu Adamu, a columnist with Daily Trust, had initially come out condemning attacks on the Muslim, Hausa-Fulani population in Jos. He was particularly angered, like Mohammed Haruna, by the position taken by the government of Plateau State and the failure of the federal government to intervene. However, he argued: 'A press that is partisan, in common with the journalist who is jaundiced, is as much incapable of telling truth to power as telling it against his group interest, and is therefore a great danger to society. Such a press and such a journalist become part of the problem rather than part of the solution....and the newspaper that will encourage this is a liability to society and will remain an obstacle to peaceful coexistence' (2008, n.p.).

Adamu also directed a suggestion to the Muslims (Hausa-Fulani) victims of the conflict in Jos to search within themselves for likely answers to their unanswered questions. He advised them to use the occasion to do a soul-searching through which they could discover the real causes of their troubles. 'If they are honest with themselves', he posited, 'they should admit that the cause of their plight couldn't have all been external' (2008 n.p.). 
Ruben Abati is also a very credible writer from the South who writes for Nigeria's Guardian. He summed up the crisis in Plateau State in one sentence as follows: 'Whereas there have been many recorded cases of violence in all parts of Plateau state, over the years, the pattern and the root causes have all been similar, and they are traceable to power politics, identity, hate and intolerance, so conveniently dressed and fired up with religion' (2008, n.p.).

Abati, like most commentators, argued there was a show of levity in handling the crisis. For example, while the entire city of Jos was burning, Nigeria's President Umaru Musa Yar'Adua found it unnecessary to even visit the area or address the nation. Instead he remained mute. He also blamed Governor Jang for proposing to inaugurate the new council chairmen, including the one whose election provoked the violence. The ruling party, according to him, always finds it difficult to draw the line and considers politics as a do or die affair.

The 'indigene' and 'settler' issue blamed by all for the entire conflicts was again fingered by Abati, who states: '...the indigene-settler dichotomy is an assault on the Nigerian constitution, which protects every Nigerian from discrimination. The fact that some Nigerians are considered settlers in their own country and discriminated against for that reason is condemnable' (2008, n.p.). His suggestion of a way forward include: the arrest of the perpetrators of the mayhem in Jos and their prosecution; the cancellation of the disputed election and the state-government kick-starting a process of reconciling the warring tribes.

But Abati, like the other writers and journalists, was, perhaps, more interested in commenting on the plight of the victims from his own part of Nigeria and religion than the others. For instance, he mentioned: 'Ibos, Yorubas and other Nigerians had no stake whatsoever in the conflict; they had no candidate in the Jos North elections...But as violence erupted, places of religious worship were targeted. The terrorist did not spare Southerners if they happened to be Christians' (2008, n.p.). Although he did mention earlier in his article that as at the last count, before he wrote, 500 lives had been lost, he did not elaborate. But he now mentioned the Yoruba, his own ethnic tribe, casualty figure, which he said had been roughly put at 113 . He also stressed the case of the Youth Corpers killed by hoodlums in Jos. At no point did he say anything about the other victims, much less the Islamiya pupils attacked and burnt to death by hoodlums or those taken from their homes and extra-judicially executed by the police.

Writing for This Day (newspaper), Simon Kolawale accused the government of not taking the issue of people's security and safety seriously, as opposed to the manner in which they (politicians) consider their own protection. He felt the situation in Jos was like a ticking bomb and should have been cautiously handled, but the government failed the citizens by throwing caution to the wind.

Quite unlike the other writers and journalists mentioned in this article, Kolawole clearly avoided linking himself to any of the factions as he said: 'My worry is not about Jos North only. I am worried about every state in Nigeria where there are minorities, who for years have been living in the shadows of the majorities and are trying to assert themselves... We are sitting on potentially serious conflicts, burying our heads in the sand and pretending everything is fine' (2008, n.p.).

Arguing further that despite having enough time to put the situation in order before it got out of control the government failed to do so, he concluded that the best way out is for mutuallynegotiated, mutually-agreed roadmap to peace to be designed. 
All those whose positions regarding the conflict were mentioned so far in this article are Nigerians from different parts of the country and belonging to the two main religions - Islam and Christianity. While they commented on the basis of their religious or tribal affiliations, except Simon Kolawole, the report by Human Rights Watch, published less than a month after the crisis, took a completely different perspective. Up until now, whereas none of its recommendations, has been implemented or taken seriously by either Plateau State or the federal government, the HRW report remains the most credible, most detribalised and completely unbiased document exposing who played what role in the conflict, including the governments and their securities operatives.

If anyone was still in doubt of the extent of damage caused and the complicity of politicians in the November 28-29, 2009 violence, the report by Human Rights Watch was to, at least, provide a clearer picture of the situation. Based on interviews with scores of eyewitnesses, Human Right Watch published a report on December 21, 2008 documenting several incidents in which police and military personnel killed over 90 civilians. It categorically noted that almost all of the victims were Muslims/Hausa/settlers and that the killings took place after the governor had issued a shoot-on-sight order. The report stated that: 'The vast majority of the killings were perpetrated by the anti-riot Police Mobile Force, commonly referred to as the MOPOLs... According to witnesses, all of these victims were Muslim men, most were young, and nearly all were unarmed at the time they were killed. Human Rights Watch urges these investigative bodies to investigate the allegations of widespread killings by security forces as well as the circumstances surrounding, and consequences of, Governor Jang's shoot-on-sight order' (Dufka, 2008, p.1).

Rather than agree on a way to deal with the allegations and bring the culprits to justice the federal and state governments were occupied with tussles over whose duty it was to maintain peace in the state. Each ended up setting its investigation panels that were sure to duplicate roles.

On the part of the media, again there was very little reported to either confirm or deny claims made in the HRC report. Only the Daily/Weekly Trust, for obvious reasons, fully published the report and made follow-up reports on the victims. Haruna Mohammed had accused the press of playing up the ethnic card and refusing to publish reports that favourably but fairly suggested the Muslim/Hausa were victims and not aggressors. Instead, he said, they were more interested in re-echoing the allegation made by the chairman of the Plateau State Chapter of the Christian Association of Nigeria (CAN), Archbishop Ignatius Kaigama that Churches and Christian property were attacked in what he described as 'carefully planned and executed' attacks. Tribune was specifically fingered as it did not only refuse to make mention of the other side and its casualties, but also came out with a banner headline thus: 'Plateau poll crisis latest: People still trapped in Churches (Daily Trust, December 3, 2008, back page).'

One of the biggest victims of the crisis is a Hausa-Fulani car dealer in Jos. His entire company was razed and nearly a thousand vehicles destroyed. However, he was hardly mentioned by his names by the newspapers even as they were taking pictures or publishing reports about his misfortune.

A story that had the complete support of the entire press, irrespective of who owned or controlled them, was the one sold by the government of Plateau State that foreign 
mercenaries were used in the conflict. In fact, although it all started as a speculation, it gained much currency when some men were intercepted as they travelled to a neighbouring state through Jos with weapons. Much more than the killings that were only reported by the HRW, this became the most topical issue. While newspapers in the South were keen to report it as a sort of confirmation that it had, in the end, been proven that foreign mercenaries were used, Daily Trust gave a blow-by-blow account of the development in order to prove that the men were not foreign mercenaries. And when the chairman of Okene Local Government came out to acknowledge that the men arrested were the vigilante he hired from Bauchi to help check the menace of armed robbers in his locality, it was Daily Trust that broke the news. Even then others continued to doubt this account, until the Police Command in Plateau State finally confirmed that the men were, indeed, not 'rented fighters' as was thought.

Using reports and comments this essay has tried to show how the press was used in different ways to further various interests during the crisis. We've seen how almost everyone showed little or no concern for national unity or general good. Research has shown that human beings are often in competition with each other in their daily interactions. There is always an attempt to elevate and promote one's interest or a group's interest over and above others', even if it is at variance with the wish of the majority. This usually leads to conflict as the various interests become irreconcilable. Conflicts arise as people struggle over scarce or limited resources. Competition, therefore, leads to antagonism, ethnocentrism, discrimination and prejudice (LeVine \& Campbell, 1972, cited in Leyens, et al., 1994, p.46).

In order to understand how such interests manifest and lead to competition and then conflict Sherif, who advanced the Realistic Conflict Theory, and his research group organised a summer camp for adolescents in 1949, 1953 and 1954 (Sherif et al., 1961).

Spanning four phases the researchers observed how group interactions are established and how cohesive groups are formed on the basis of competition and conflict. The first phase of the study saw the researchers creating two independent groups with specific norms, leadership and network affinities. Two teams were then created further, for one of the camps without each knowing about the existence of the other. But participants were allowed to freely interact in all other cases and even establish friendship before low cohesive groups were formed by separating good friends.

Within the first five days the newly formed groups were again highly cohesive and ready to attack others in a bid to defend their groups, based on the names they chose.

The second phase saw the participants facing each other in competitive games, resulting in conflicts, names calling, raids etc. The win or lose situation (special) competition introduced by the researchers earned the study the name Realistic Conflict Theory. However, this hostility amongst participants intensified as each sought to promote their group's interest.

In the third phase effort was made by the researcher to douse tension and reduce hostility but failed, despite introducing positive information about the groups. Not even the leaders of the groups tried to intercede as they became part of the crisis, clearly benefiting from it.

The introduction of Superordinate Goals (SG) by Muzafer Sherif had an immediate impact on the situation. These are goals that can only be achieved through interdependence and cooperation. The goals arise where there is a common enemy from outside or a common problem from within (Leyens, et al., 1994, p.46). During the study SG was successful in restoring harmony between the groups. 
It is essential at this juncture to ponder the possibility of applying this theory in the Nigerian context. The huge gulf between the people developed as they competed over the country's limited resources. In Jos, for example, the local government post that controls large sums of public funds disbursed by the federal government was the coveted trophy (HRW, Dec 2008). But the media, the politicians and the clergy, as some have argued, failed to intercede, perhaps, because they were in one way or the other benefiting from the conflict. In the case of Nigeria can religious affiliations and tribal/ethnic allegiances be set aside in order to achieve a Superordinate Goal? Are there Superordinate Goals to be used in uniting the people and restoring harmony?

An alternative school of thought which seeks to achieve the same results as the RCT is the Social Identity Theory (SIT). Propounded by Henri Tajfel (1969, cited in Leyens et al., 1994, p.54) SIT argues that symbolic rather than material resources are responsible for conflicts. Issues like status, self esteem and beliefs, therefore, override objective benefits in importance. It further lays emphasis on the importance of interdependence for members of a group as they become aware that their destiny depends on it. Rabbie (1991, cited in Leyens, et al., 1994) notes that people form a group when they are aware of the interdependence of their destiny.

One of SIT areas of focus is in-group favouritism that is usually induced by factors like shared fate or objective competition. Being in a group and knowing that the other person belongs to a different group is enough reason to create prejudice even without knowing that person. In Northern Ireland several studies on how in-group favouritism could lead to outgroup prejudice have been conducted and solutions, leading to reduction of prejudice, proffered. Contact Hypothesis is one possible way.

In Nigeria, as we have discussed earlier, the press are mainly based in Lagos (Southern Nigeria); they are owned and controlled by proprietors who are non-Northerners. Even when they are not, Northern audience would consider them anti-North. Meanwhile, the big question is whether there have been deliberate, comprehensive attempts to apply content hypothesis in order to make Nigerians, particularly journalists, understand and report the positive sides of the other culture? By understanding Islam as anything other than a militant religion and portraying this in reports a conscious effort is made to reduce suspicion. Muslim/Northern writers who see and present Christians/Southerners in a better and friendlier picture would also earn the respect of Southerners.

In conclusion, this paper proposes identifying important goals of national relevance, studying those and striving to achieve them by means of interdependence and cooperation, while setting aside hostility or prejudice. It also proposes promoting the study of other cultures and religious faiths, in schools and colleges, especially where journalists are trained; this will help in laying a better foundation for the reduction of in-group favouritism and out-group prejudice. This could be a way forward.

In achieving these propositions it is necessary to examine certain issues within the polity in relation to our collective willingness to effect the desired change needed to move the country forward. According to Sherif's RCT we can only achieve Superordinate Goals by means of interdependence and cooperation. At this point we must identify what, in our specific situation, are Superordinate Goals. The most important thing binding us together is our collective interest as members of a country, despite the fact that Nigeria is a colonial creation. As Simon Kolawole pointed out the country is sitting on potentially serious conflicts and 
wishing it away is simply not a solution. In the face of this reality our first Superordinate Goal may be our collective survival as a nation, since disintegration is not desirable; even if it is desired, it may be so desired by a few and for their own interests. Thus, there is a need to understand our different preferences as members of a political entity and reconcile those amicably. Again, Kolawole has suggested drawing up a roadmap that would allow for such reconciliation. In a country of scores of minority ethnic groups sandwiched by a few majority tribes, ensuring equality and fairness is a huge task that must not be compromised. A number of suggestions have been made in a bid to reach a consensus on the kind of Nigeria every interest group or ethnic nationality would consider desirable. One suggestion that has repeatedly featured is the convening of a Sovereign National Conference to discuss problems and forge a way forward. How this would resolve the major problems the country faces remains unclear, but the vehemence with which advocates of this proposal speak tells one that there is a general resolve to find a solution to the problem, somehow. The danger is if a roadmap is not fashioned out and a peaceful resolution process kick-started violence would continue to be seen by a number of desperate Nigerians as the only way out.

A few years ago, a group of top American experts on Sub-Saharan Africa rose from a conference predicting horrible events that would occur in Africa unless something was done to checkmate them. Nigeria's disintegration was one of the events they said would shockingly happen. In a US National Intelligence Council report titled 'Mapping Sub-Saharan Africa's Future' it is forecasted that Nigeria will, within 15 years, become 'a failed state, dragging down a large part of the West African region' following certain ecological downturn and conflict over water' (Anon., 2005, n.p.). A more horrifying aspect of the report is that Nigeria would finally collapse and this process would be sparked by 'a junior officer coup' leading to the outbreak of open warfare in many parts of the country. Again rather than wait for any of these predictions to happen or sit and wish them away there is a need for a pause and rethink on the part of the leadership and people.

In Northern Ireland, one of the means via which hostility and prejudices between the Catholics and Protestants were reduced was the application of Contact Hypothesis. Contact Hypothesis is a strategy applied under the Social Identity Theory to resolve inter-ethnic or inter-group conflicts as is the case with Nigeria. The SIT was earlier in this essay discussed and there was a suggestion to study other cultures and religious faiths so as to reduce ingroup favouritism and out-group prejudice. In a practical situation is there any chance of shedding negative impressions or beliefs about others after having a direct contact with them? There is no direct yes or no answer to this. But the success of contact hypothesis in resolving major problems depends mainly on the individuals on whom the technique is applied as well as a number of variables. First, are they, themselves, willing to come to a dialogue with an open mind? Are they ready to honestly say their mind and listen to others say what they have on their mind? Would they treat the other party with complete respect and equality at least while the dialogue lasts? And finally, would they be able to forgive, forget and move on? It is only after these and many other issues have been understood and agreed that the contact hypothesis technique could be given a chance to help warring parties overcome their differences.

In schools the study of other faiths and cultures could be a first step to preparing people's mind on the possibility of SIT contact hypothesis being applied. One of the striking features of the Northern Irish society is the extent to which the two religious communities have been segregated (Hewstone, et al., 2005, p. 267). This level of polarisation is also clearly demonstrated in the school, housing and marriage patterns. For instance schools attended by 
Catholics are not attended by Protestants. The same applies to the housing situation, where Protestants live separately from Catholics. There is also a problem of keeping friends from faith other than yours and this affects relationship and marriage.

Although Nigeria is not as polarised as Northern Ireland, some parts of the country are beginning to experience it. In Jos, as was earlier mentioned, there are places where Muslims are in majority and are distinctly inhabited by Muslims. Also there are areas that Christians exclusively live and Muslims cannot live or visit there. Christians can also not visit those areas where only Muslims live. Invariably, this problem affects school attendance, friendship and marriage too. It is important to note that young people, especially children, can be influenced by happenings around them. They have several opportunities to learn about violence, but hardly have peace defined for them (Schwebe, 2001; McLernon \& Cairns, 2001; cited in Kool, 2008, p. 70). Kool (2008) explains that children know more about the absence of violence, negative peace, than they know about promoting harmonious existence. School lessons about the positive aspects of other religious faiths and cultures will help in reducing the chances of developing negative impressions of others. In Nigeria, making this part of the curriculum for journalism training will help in making journalists that will see beyond their ethnic cocoons or religious views when reporting other faiths and cultures. By and large, what the Nigerian society needs are people that would be able to rise above religious and or ethnic divisions and promote the sort of harmonious relations that would make the prediction that the country would collapse by 2020 a non-reality and ensure that the current circle of violence is broken.

\section{BIBLIOGRAPHY}

Abati, R. 'Politics and the Devil's Parking Space in Jos', The Guardian [Online edition], Available at: http://www.ngrguardiannews.com/editorial_opinion/article02//indexn2_html?pdate $=05120 \&$ ptitle=Politics\%20and\%20the\%20Devil's\%20parking\%20space\%20in\%20Jos. [Accessed: 5 December 2008].

Adamu, A. (2008) 'Jos and Epidemic Insanity [I]', Daily Trust [Online Edition], Available at: http://allafrica.com/stories/200812120165.html [Accessed: 5 December 2008].

Adamu, A. (2008) 'Jos and Epidemic Insanity [III]', Daily Trust [Online Edition], Available at:http://news.dailytrust.com/index.php?option=com_content\&task=view\&id=456\&Itemid=1 [Accessed: 12 December 2008].

Anon., (2005) 'Mapping Sub-Saharan Africa's Future', Conference Summary, National Intelligence Council [Internet], Available at: http://www.dni.gov/nic/confreports_africa_future.html [Accessed: 23 June 2010].

Danmole, H.O. (1999) 'Media Use of Muslims in South-Western Nigeria: Parallels and Comparisons', Paper read at Religion and Media in Africa, at SOAS, London.

Dufka, C. (2008) Arbitrary Killings by Security Forces: Submission to the Investigative Bodies on the November 28-29, 2008 Violence in Jos, Plateau State, Nigeria. New York: Human Rights Watch. 
Falola, T. (1998) Violence in Nigeria: The Crisis of Religious Politics and Secular Ideologies. Rochester: University of Rochester Press.

Hackett, R. I. (2003) 'Managing or Manipulating Religious Conflict in the Nigerian Media'. In: Mitchell, J. \& Marriage, S. eds., Mediating Religion: Conversations in Media, Religion and Culture. Edinburgh: T \& T Clark. Chapter 5.

Jos, Ahmed S. (2007) 'The Foundation of Jos' [internet] 7 March. Available at: http://www.amanaonline.com/jos/jos_01.htm [Accessed: 23 June 2010].

Haruna, M. (2008) 'The Media and the Genocide in Jos', Daily Trust [Online Edition], Available at:

http://news.dailytrust.com/index.php?option=com_content\&task=view\&id=349\&Itemid=1:te stset [Accessed: 3 December 2008].

Haruna, M. (2008) 'Still on the media and the genocide in Jos', Daily Trust [Online Edition], Available at: http://allafrica.com/stories/200812120530.html [Accessed: 10 December 2008).

Hewstone, M, Cairns, Voci, A., Paolini, S., McLernon, F., Crisp, R \& Niens, U. (2005) 'Intergroup Contact in a Divided Society: Challenging Segregation in Northern Ireland', In: Abrams, D., Hogg, M. A., \& Marques, J. M., eds. The Social Psychology of Inclusion and Exclusion. New York: Psychology Press. Chapter 12.

Ibrahim, J. (1989) 'The Politics of Religion in Nigeria: The parameters of the 1987 crisis in Kaduna State', Review of African Political Economy, 45/46: 65-82.

Jos, Ahmed S. (2007) 'The Foundation of Jos' [internet] 7 March. Available at: http://www.amanaonline.com/jos/jos_01.htm [Accessed: 23 June 2010].

Kaldor, M. (2006) New and Old Wars. Cambridge: Polity Press.

Kolawole, S. (2008) 'Nigeria Fails Us...Yet Again.' This Day [Online Edition], Available at: http://www.thisdayonline.com/nview.php?id=130132 [Accessed: 7 December 2008].

Kool, V. K. (2008) Psychology of Nonviolence and Aggression. New York: Palgrave Macmillan.

Kukah, M. H., \& Toyin, F. (1996) Religious Militancy and Self Assertion: Islam and Politics in Nigeria. Aldershot, UK: Avebury.

Leyens, J., Yzerbyt, V., \& Schadron, G. (1994) Stereotypes and Social Cognition. London: Sage Publications.

Mohammed, A. (2002) 'Why Newspapers fail in northern Nigeria' Paper read at Graduate Seminar Centre for Journalism Studies, Wales.

Osinubi, T.S., \& Osinubi, O.S. (2006) 'Ethnic Conflict in Contemporary Africa- the Nigerian Experience', Journal of Social Sciences, 12/2: 101-114. 
Plateau State, n.d. 'Home of Peace \& Tourism', (Internet), Available at: http://www.plateaustate.gov.ng/?ContentPage\&sub_cnt=sectionpage\&secid=16\&sub_cntid= 174. [Accessed: 26 June 2010].

Salawu, A. (2006) 'Rich History, Uncertain Future', Rhodes Journalism Review, 26, September: $55-56$.

Sherif, M., Harvey, O.J., White, B.J., Hood, W.R., \& Sherif, C.W. (1961) Intergroup conflict and Cooperation: The Robbers Cave Experiment, Norman, O.K.: University Book Exchange.

Volkan, V. D. (2006) Killing in the Name of Identity: A Study of Bloody Conflicts.

Charlottesville, V.A.: Pitchstone Publishing.

Zimbardo, P. G. (2008) The Lucifer Effect: How Good People Turn Evil. London: Random House. 